\title{
Motivasi Berprestasi dan Kemandirian Belajar Mahasiswa saat Pembelajaran Daring
}

\author{
Windi Fitriani ${ }^{1}$, Haryanto $^{2}$, Setyo Eko Atmojo ${ }^{3}$ \\ 1, 2 Pendidikan Dasar-Universitas Negeri Yogyakarta \\ ${ }^{3}$ Pendidikan Guru Sekolah Dasar-Universitas PGRI Yogyakarta
}

\begin{tabular}{l}
\hline INFO ARTIKEL \\
\hline Riwayat Artikel: \\
Diterima: 14-12-2019 \\
Disetujui: 22-06-2020 \\
\hline Kata kunci: \\
independent learning; \\
achievement motivation; \\
online learning; \\
kemandirian belajar; \\
motivasi berprestasi; \\
pembelajaran daring
\end{tabular}

Alamat Korespondensi:

Windi Fitriani

Pendidikan Dasar

Universitas Negeri Yogyakarta

Jl. Colombo No. 1, Karang Malang, Caturtunggal, Kecamatan Depok, Kabupaten Sleman, Daerah Istimewa Yogyakarta 55281 E-mail: windifitriani.2019@student.uny.ac.id

Pendidikan abad 21 mengalami perubahan yang signifikan terkait pemanfaatan teknologi informasi dan komunikasi dalam pembelajaran. Alih-alih harus tatap muka, pembelajaran dapat dilakukan melalui jaringan atau dikenal dengan istilah pembelajaran dalam jaringan. Pembelajaran dalam jaringan (daring) oleh I. E. Allen, Seaman, Poulin, dan Straut (2016) didefinisikan sebagai pembelajaran dimana minimal $80 \%$ dari isi pembelajaran/materi disampaikan secara daring, sedangkan sisanya adalah proporsi untuk tatap muka, atau bahkan tanpa muka sama sekali. Pembelajaran daring menjadi alternatif yang menawarkan fleksibilitas dan aksesibilitas dibanding pembelajaran tatap muka terkait penentuan waktu dan lokasi belajar (Broadbent \& W. L., 2015). Selain itu, partisipan juga memiliki kesempatan yang lebih besar untuk mempelajari informasi, menambah akses sumber belajar, serta kesempatan kolaborasi yang besar. Dengan meningkatnya aksesibilitas internet dalam sepuluh tahun terakhir, Bowers dan Kumar (2015) menyebutkan bahwa pembelajaran daring telah menjadi bagian integral dari kebanyakan institusi pendidikan tinggi.

Terlepas dari keuntungan-keuntungan tersebut, terdapat tantangan tersendiri dalam pembelajaran daring jika dilihat dari sisi pengajar dan pembelajar. Dalam pembelajaran daring, dosen cenderung mengajar dan mengembangkan situasi belajar seperti terisolasi sehingga menyebabkan mahasiswa menarik diri dan pada akhirnya menjadi salah satu faktor pemicu kegagalan (Capra, 2011). Oleh karena itu, bagi siapa saja yang mengikuti pembelajaran daring diharapkan untuk memiliki kemampuan mengendalikan, mengelola, dan merencanakan tindakan belajar mereka (Ally, 2004). Mengingat pada dasarnya sifat dari pengaturan daring menurut B. K. Allen, Romney, Dey, dan Romney (2015) adalah pembelajaran mandiri, maka kesuksesan pembelajaran daring sangat bergantung pada kemampuan mahasiswa untuk terlibat aktif serta mandiri selama proses dan di luar pembelajaran (Wang, Shannon, \& Ross, 2013; Lehmann, Hähnlein, \& Ifenthaler, 2014). 
Menggunakan istilah self-directed learning, Knowles (1975) menyebutkan bahwa seorang individu dikatakan mandiri belajar ketika individu tersebut mampu berinisiatif meski dengan atau tanpa bantuan pihak lain, mampu menentukan tujuan pembelajaran, mengidentifikasi materi ajar, memilih kemudian mengimplementasikan strategi pembelajaran yang sesuai, dan dapat mengevaluasi hasilnya. Dengan adanya kemandirian belajar, seorang individu akan termotivasi untuk selalu bertanggung jawab terhadap pembelajaran, serta dapat memantau dan menyusun pengalaman belajar sendiri, meskipun tanpa pengawasan dan bimbingan langsung dari instruktur atau sesama pelajar (Keirns, 1999; Mota \& Scott, 2014). Tidak hanya diperlukan dalam pembelajaran formal, lebih jauh lagi, kemandirian belajar berguna untuk membekali mahasiswa agar siap menghadapi kompetisi di dunia kerja, terutama selama abad ke-21 dan era globalisasi. Oleh karena itu, tidak heran jika terwujudnya kemandirian belajar menjadi salah satu tujuan pendidikan di sebagian besar negara, terutama pendidikan tinggi (Mckendry \& Boyd, 2012; Balapumi \& Aitken, 2012; Ros, Keo, \& Sophal, 2012).

Sebagai orang dewasa, kemandirian belajar mahasiswa diharapkan lebih tinggi. Hal ini didasarkan pada pendapat Keirns (1999) bahwa orang dewasa memiliki karakteristik, antara lain memiliki kemandirian, memiliki peran aktif sebagai pembelajar, memiliki lebih banyak pengalaman sebagai sumber belajar, dan bertanggung jawab terhadap pembelajaran sendiri. Perilaku mandiri belajar berhubungan dengan beberapa faktor lain, seperti kematangan, kontrol diri, pemantauan diri, persepsi terhadap lingkungan, serta motivasi berprestasi (Keirns, 1999; du Toit-Brits \& van Zyl, 2017). Dibandingkan persepsi terhadap lingkungan, motivasi berprestasi memiliki persentase pengaruh yang lebih besar terhadap kemandirian belajar (Huang, 2008). Motivasi berprestasi oleh Diggory, Heckhausen, Butler, Birney, dan McClelland (1968) didefinisikan sebagai upaya untuk meningkatkan atau mempertahankan setinggi mungkin kemampuan diri sendiri dalam semua kegiatan berdasarkan standar keunggulan yang berlaku, meskipun dalam melakukan kegiatan tersebut memiliki kemungkinan berhasil atau gagal. Seorang individu dengan motivasi optimal memiliki sikap dan strategi yang adaptif (selalu menyesuaikan keadaan) yang meliputi kemampuan untuk mempertahankan motivasi intrinsik, menetapkan tujuan yang akan dicapai, serta dapat memantau dirinya sendiri sehingga pada akhirnya mereka menjadi individu yang unggul (Alderman, 2004).

Berdasarkan beberapa pendapat tersebut, terlihat adanya keterkaitan antara motivasi berprestasi dengan perilaku kemandirian belajar. Penelitian yang dilakukan oleh David, Matulessy, dan Pratikto (2014) menunjukkan bahwa motivasi berprestasi memiliki hubungan yang positif dan secara statistik signifikan dengan kemandirian belajar. Penelitian lain juga dilakukan oleh Chairani (2017), motivasi secara langsung memengaruhi kemandirian belajar karena motivasi berkaitan dengan pemilihan strategi dan tindakan seseorang. Berdasarkan penelitian Baars dan Wijnia (2018), individu dengan motivasi otonom lebih tinggi menunjukkan perolehan hasil belajar yang lebih tinggi serta akurasi pemantauan diri yang lebih baik. Dengan kata lain, mereka dapat belajar dengan lebih baik serta meningkatkan kinerja tugas mereka. Penelitian ini bertujuan untuk memeriksa hubungan motivasi berprestasi dengan kemandirian belajar mahasiswa PGSD saat pembelajaran daring, apakah dalam kategori lemah, sedang, atau kuat. Dengan memeriksa keterkaitan kedua variabel tersebut, diharapkan nantinya bisa menjadi masukan dan pertimbangan bagi dosen dalam menanamkan kemandirian belajar pada mahasiswa.

\section{METODE}

Penelitian menggunakan pendekatan kuantitatif jenis ex post facto, di mana tidak ada manipulasi, perlakuan, dan pemberian tugas pada subjek (Kerlinger, 1964). Penelitian ini termasuk studi korelasional yang berusaha untuk menentukan ada tidaknya hubungan, serta sejauh mana hubungan antara dua variabel yang dapat diukur (Gay, 1976). Dalam hal ini, penelitian dimaksudkan untuk mengetahui ada atau tidaknya hubungan antara motivasi berprestasi dan kemandirian belajar mahasiswa, serta seberapa besar hubungan antara kedua variabel.

Populasi dalam penelitian adalah mahasiswa PGSD semester 2 Universitas PGRI Yogyakarta sebanyak 237 mahasiswa. Simple random sampling dipilih sebagai teknik pengambilan sampel, sedangkan ukuran sampel ditentukan berdasarkan perhitungan sampling error formula yang didasarkan pada peluang atau proporsi bahwa sampel dibagi secara merata berdasarkan pertanyaan, kesalahan pengambilan sampel, serta interval kepercayaan (Creswell, 2012). Berdasarkan Tabel Fowler dengan proporsi 50/50, tingkat kesalahan pengambilan sampel sekitar 7-10\%, dan interval kepercayaan sebesar 95\%, maka sampel yang diambil secara random sebanyak 165 mahasiswa.

Teknik pengumpulan data dilakukan melalui survey (Creswell, 2012) menggunakan instrumen angket motivasi berprestasi dan kemandirian belajar saat pembelajaran daring. Angket motivasi berprestasi memuat 14 pernyataan dari indikator yang dikembangkan oleh Atkinson (Sujarwo, 2013) yang terdiri atas enam indikator, meliputi (1) adanya tanggung jawab tinggi terhadap tugas; (2) mampu menetapkan tujuan yang menantang, sulit, tapi realistik; (3) tidak takut akan kegagalan; (4) adanya keyakinan untuk sukses; (5) berusaha sungguh-sungguh dalam mencapai sukses; 6) berusaha untuk memperoleh hasil yang terbaik. Sementara indikator kemandirian belajar menggunakan indikator yang dikembangkan oleh Danuri (Widiyanto, 2013) yang terdiri atas lima aspek, yaitu (1) adanya kecenderungan perilaku yang bebas untuk berinisiatif, bersikap, atau berpendapat; (2) adanya kepercayaan diri; (3) memiliki sifat asli yang bukan sekadar mengikuti orang lain; (4) tidak mengharapkan arahan dari orang lain; (5) adanya inisiatif sendiri dalam berperilaku. Indikator tersebut dijabarkan dalam 16 butir pernyataan. 
Sebelum digunakan untuk penelitian, instrumen diujicobakan terlebih dahulu pada responden selain sampel yang berjumlah 37 responden untuk membuktikan validitasnya. Selanjutnya, butir yang valid dengan $r_{\text {hitung }}>0.325$ digunakan untuk penelitian. Hasil uji reliabilitas pada butir yang telah valid dihasilkan nilai Cronbach's Alpha sebesar 0.854 untuk angket motivasi berprestasi dan 0.847 untuk angket kemandirian belajar. Nilai tersebut lebih besar dari $r_{\text {tabel }}(0.325)$ sehingga instrumen dikatakan reliabel. Tahap berikutnya yaitu uji asumsi dengan uji normalitas residual untuk mengetahui apakah kenormalan distribusi data. Apabilan signifikansi > 0.05, maka data dikatakan berdistribusi normal.

Teknik analisis data yang digunakan dalam penelitian ini adalah analisis deskriptif (Sugiyono, 2013). Mardapi (Adib, 2015) hasil analisis deskriptif ditampilkan dalam bentuk tabel kecenderungan variabel, diagram pencar hubungan antara motivasi berprestasi dan kemandirian belajar, serta uji korelasi menggunakan Product Moment yang dihitung dengan SPSS versi 22 . Tujuan uji korelasi adalah untuk mengetahui ada atau tidaknya hubungan antara motivasi berprestasi dan kemandirian belajar, serta jika terdapat hubungan, maka seberapa besar koefisien hubungan tersebut. Lebih lanjut, nilai R pada koefisien korelasi digunakan untuk mencari besarnya koefisien determinasi yang berguna untuk mengukur variabel motivasi berprestasi dalam memprediksi kemandirian belajar (Modul PPJFP: Analisis Data dan Interpretasi hasil Penelitian IPS, 2019).

\section{HASIL}

Analisis deskriptif yang ditampilkan pada tabel 1 memuat skor terendah, skor teringgi, mean, mean ideal (Mi), standar deviasi, dan standar deviasi ideal (SDi) untuk masing-masing variabel. Nilai yang didapatkan dari hasil analisis deskriptif ini kemudian digunakan sebagai dasar untuk mengetahui kecenderungan masing-masing variabel. Berdasarkan tabel 2 terlihat bahwa sebanyak 30\% (50) mahasiswa memiliki motivasi berprestasi sangat tinggi, 34\% (56) memiliki motivasi berprestasi tinggi, 30\% (49) motivasi berprestasinya rendah, dan sisanya memiliki motivasi berprestasi sangat rendah sebanyak 6\% (10) mahasiswa. Sementara itu, untuk kemandirian belajar sebanyak 64\% (106) memiliki kemandirian belajar sangat tinggi, 29\% (47) kemandirian belajar tinggi, 6\% (10) kemandirian belajarnya rendah, serta sisanya memiliki kemandirian belajar sangat rendah dengan persentase $1 \%$ (2). Hasil uji normalitas residual menghasilkan angka 0.062 yang bisa dilihat pada pada tabel 4 kolom Asympt. Sig (2-tailed). Nilai signifikansi variabel lebih besar dari 0.05 sehingga dapat dikatakan distribusi data adalah normal.

Tabel 1. Deskripsi Data

\begin{tabular}{ccccccc}
\hline Variabel & $\begin{array}{c}\text { Skor } \\
\text { minimal }\end{array}$ & $\begin{array}{c}\text { Skor } \\
\text { maksimal }\end{array}$ & Mean & $\begin{array}{c}\text { Mean ideal } \\
\text { (Mi) }\end{array}$ & $\begin{array}{c}\text { Standar } \\
\text { Deviasi }\end{array}$ & $\begin{array}{c}\text { Standar deviasi } \\
\text { Ideal (SDi) }\end{array}$ \\
\hline Motivasi berprestasi & 29 & 56 & 44.0667 & 42.5 & 4.46150 & 4.5 \\
Kemandirian belajar & 35 & 64 & 51.8303 & 44.5 & 5.50014 & 4.8 \\
\hline
\end{tabular}

Tabel 2. Kecenderungan Variabel Motivasi Berprestasi

\begin{tabular}{cllcc}
\hline No. & Interval & Kategori & Frekuensi & Persentase \\
\hline 1 & $X>47$ & Sangat tinggi & 50 & $30 \%$ \\
2 & $47 \geq X \geq 42.5$ & Tinggi & 56 & $34 \%$ \\
3 & $42.5 \geq X \geq 38$ & Rendah & 49 & $30 \%$ \\
4 & $X<38$ & Sangat rendah & 10 & $6 \%$ \\
\hline \multicolumn{2}{r}{ Total } & & 165 & $100 \%$ \\
\hline
\end{tabular}

Tabel 3. Kecenderungan Variabel Kemandirian Belajar

\begin{tabular}{cllcc}
\hline No. & Interval & Kategori & Frekuensi & Persentase \\
\hline 1 & $X>49.3$ & Sangat tinggi & 106 & $64 \%$ \\
2 & $49.3 \geq X \geq 44.5$ & Tinggi & 47 & $29 \%$ \\
3 & $44.5 \geq X \geq 39.7$ & Rendah & 10 & $6 \%$ \\
4 & $X<39.9$ & Sangat rendah & 2 & $1 \%$ \\
\hline \multicolumn{2}{r}{ Total } & & 165 & $100 \%$ \\
\hline
\end{tabular}

Tabel 4. Hasil Uji Normalitas

\begin{tabular}{ccc}
\hline Banyaknya sampel (N) & Asymp. Sig. (2-tailed) & Keterangan \\
\hline 165 & 0.062 & Distribusi Normal \\
\hline
\end{tabular}


Tabel 5. Hasil Uji Hipotesis

\begin{tabular}{ccccc}
\hline Variabel & Sig. (2-tailed) & Pearson Correlation $(\boldsymbol{R})$ & $\boldsymbol{R}$ Square $\boldsymbol{( R}^{\mathbf{2}}$ ) & Persentase \\
\hline $\begin{array}{l}\text { Motivasi berprestasi } \\
\text { Kemandirian belajar }\end{array}$ & 0.000 & 0.702 & 0.490 & $49 \%$ \\
\hline
\end{tabular}

Sementara itu, uji hipotesis yang dilakukan menggunakan korelasi Product Moment menghasilkan nilai signifikansi serta besarnya koefisien korelasi. Hubungan kedua variabel dikatakan signifikan apabila nilai signifikansinya $<0.05$. Berdasarkan analisis data, dihasilkan nilai signifikansi variabel 0.000 yang berarti $<0.05$, sehingga kedua variabel tersebut memiliki hubungan signifikan. Besarnya hubungan kedua variabel ditentukan dari nilai Pearson Correlation (R) dengan hasil sebesar 0.702. Selanjutnya, hasil koefisien determinasi menghasilkan nilai 0.490 atau jika diubah dalam bentuk persen menjadi $49 \%$. Hasil nilai signifikansi, koefisien korelasi, dan koefisien determaniasi dirangkum pada tabel 5.

Hubungan antara motivasi berprestasi dengan kemandirian belajar juga ditampilkan pada gambar 1. Persebaran titik-titik pada diagram pencar menghasilkan bentuk oval yang mengarah ke kanan. Ini berarti hubungan kedua variabel merupakan hubungan yang positif.

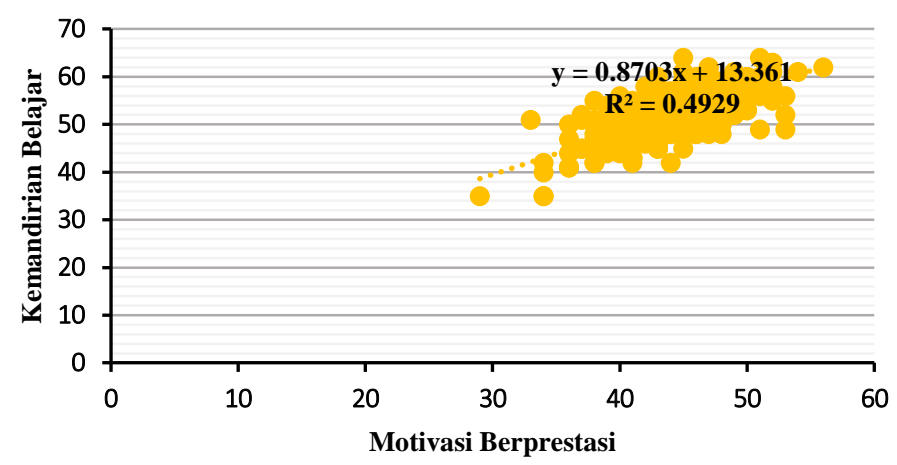

Gambar 1. Diagram Pencar Hubungan Motivasi Berprestasi dengan Kemandirian Belajar

\section{PEMBAHASAN}

Dalam pandangan teori kognitif sosial, keberhasilan pembelajaran ditentukan oleh adanya interaksi antara pembelajar dengan lingkungan. Interaksi yang tinggi ini menurut Whitaker (2017) merupakan ciri dari komunitas pembelajar di perguruan tinggi. Meskipun begitu, interaksi tidak menjamin adanya keterlibatan kognitif secara bermakna. Interaksi kelompok yang tinggi mungkin hanya cerminan dari ikatan kelompok, tetapi secara langsung menciptakan perkembangan kognitif atau pembelajaran yang bermakna. Dalam pembelajaran daring yang yang kian marak di abad 21 ini, permasalahan yang terjadi adalah kurangnya interaksi dan "kehadiran" pengajar maupun pembelajar dalam komunitas belajar. Hal ini tentu akan memengaruhi keberhasilan pembelajaran. Oleh karena minimnya interaksi tersebut, maka konsekuensinya adalah harus adanya kemandirian belajar dalam diri mahasiswa. Mahasiswa yang mempunyai kemandirian belajar akan memiliki inisiatif sendiri ketika belajar, tanpa tergantung dari pihak lain. Selain itu, menurut du Toit-Brits dan van Zyl (2017), orang yang memiki kemandirian belajar berarti memiliki motivasi diri yang kuat.

Hasil yang ditunjukkan oleh penelitian ini membuktikan adanya hubungan yang signifikan antara motivasi berprestasi dan kemandirian belajar mahasiswa PGSD saat pembelajaran daring yang ditunjukkan dengan nilai signifikansi sebesar 0.000. Sementara itu, uji hipotesis dengan korelasi Product Moment menghasilkan koefisien korelasi sebesar 0.702. Jika dikategorikan berdasarkan pedoman interpretasi koefisien korelasi, nilai tersebut berada pada rentang 0.60-0.799 (Sugiyono, 2019), yang termasuk dalam kategori kuat. Hasil tersebut sejalan dengan hasil penelitian yang dilakukan David et al. (2014), bahwa motivasi berprestasi dan kemandirian menghasilkan korelasi parsial sebesar 0.775 serta nilai signifikansi sebesar 0.000 yang berarti terdapat hubungan positif yang signifikan pada kedua variabel tersebut. Individu dengan motivasi berprestasi ditandai dengan adanya sikap menyukai pekerjaan yang memerlukan tanggung jawab pribadi. Penelitian lain yang juga sejalan adalah penelitian Chairani (2017), Aprilia, Witurachmi, dan Hamidi (2017) serta Baars dan Wijnia (2018). Mahasiswa dengan motivasi tinggi akan memiliki kemandirian yang tinggi pula yang ditunjukkan melalui strategi dan inisiatif dalam belajar. Strategi dan inisiatif tersebut timbul karena adanya motivasi (Chairani, 2017). Pernyataan tersebut sesuai dengan pendapat Santrock (2010) bahwa motivasi 
akan memberikan semangat, arah, dan kegigihan dalam melakukan sesuatu. Selain itu, fungsi motivasi menurut Ford (Alderman, 2004) yaitu (1) memberikan energi atau mengaktifkan perilaku pada apa yang membuat individu terlibat, atau berubah menuju belajar; (2) mengarahkan perilaku, mengapa satu tindakan dipilih daripada lainnya; (3) mengatur perilaku, mengapa seseorang bertahan menuju tujuan.

Hasil penelitian ini juga membuktikan bahwa hubungan antara motivasi berprestasi dan kemandirian belajar merupakan hubungan yang bersifat positif. Artinya, semakin tinggi motivasi berprestasi seseorang (X), maka semakin tinggi kemandirian belajarnya (Y); dan semakin rendah motivasi berprestasi (X), maka semakin rendah pula kemandirian belajarnya (Y). Hubungan positif antara kedua variabel juga ditunjukkan oleh diagram pencar pada gambar 1. Persebaran titik-titik pertemuan antara kedua variabel menghasilkan bentuk oval. Hal ini menandakan hubungan kedua variabel bukanlah hubungan yang sempurna. Artinya, setiap ada kemandirian belajar tidak selalu karena adanya motivasi berprestasi. Hal dibuktikan dengan uji koefisien determinasi 0.490 atau $49 \%$. Artinya, variabel motivasi berprestasi turut berkontribusi sebesar $49 \%$ terhadap kemandirian belajar, atau dengan kata lain, 49\% kemandirian belajar ditentukan oleh faktor motivasi berprestasi dan sisanya sebesar 51\% ditentukan oleh faktor lainnya. Hal ini sesuai dengan pendapat Keirns (1999), Huang (2008), serta du Toit-Brits dan van Zyl (2017) bahwa terdapat faktor lain yang memengaruhi kemandirian belajar, seperti kematangan, persepsi terhadap lingkungan belajar, kontrol diri, maupun pemantauan diri. Berdasarkan penelitian ini, motivasi merupakan faktor yang memberikan kontribusi besar terhadap kemandirian belajar. Penelitian yang dilakukan Huang (2008) juga menunjukkan bahwa dibanding persepsi terhadap lingkungan belajar yang hanya memiliki pengaruh sebesar 3.4\%, motivasi berprestasi memberikan pengaruh lebih besar terhadap kemandirian belajar, yaitu sebesar $22.3 \%$.

Mandiri dalam belajar merupakan kemampuan yang sangat penting untuk dimiliki oleh mahasiswa atau pembelajar pada umumnya, bukan hanya saat pembelajaran dalam situasi formal di lembaga pendidikan. Dalam keadaan masyarakat yang kompleks dan semakin cepat berubah, menurut Abou-Rokbah (Kan'an \& Osman, 2015), kemandirian belajar sangat diperlukan agar seorang individu bisa tetap bertahan. Jadi, kemandirian belajar merupakan bekal yang diperlukan tidak terbatas saat melakukan pembelajaran formal karena belajar merupakan proses yang berlangsung sepanjang hayat. Setelah mengetahui adanya hubungan positif antara motivasi belajar dengan motivasi berprestasi, maka penting bagi dosen untuk membantu menumbuhkan motivasi berprestasi pada diri mahasiswa, atau mahasiswa secara pribadi menumbuhkan motivasi berprestasinya. Monks (David et al., 2014) motivasi berprestasi termasuk motivasi sosial yang dipengaruhi oleh lingkungan, meliputi keluarga, institusi pendidikan, dan teman sebaya. Kurita dan Zarbatany (1991) menyatakan bahwa beberapa cara yang ditempuh untuk meningkatkan motivasi berprestasi, meliputi (1) memberikan komentar terkait tugas yang diberikan (misalnya memberikan umpan balik individual, spesifik, dan non-normatif mengenai kinerja tugas) yang lebih menyoroti kepada informasi daripada aspek pengendalian umpan balik; (2) memberikan tugas akademik yang menginduksi persepsi lokus kausalitas sehingga secara positif memengaruhi motivasi. Selain itu, menurut teori pembelajaran sosial oleh Bandura dan Schunk (Kurita \& Zarbatany, 1991), salah satu sumber motivasi diri berasal dari penetapan tujuan dan evaluasi diri terhadap perilaku. Melalui penentuan tujuan, akan terbangun standar personal untuk penguasaan. Tujuan yang ditetapkan harus kecil, spesifik, dan jangka dekat karena tujuan yang besar, tidak jelas, atau terlalu jauh lebih kecil kemungkinannya untuk dikejar. Dengan menumbuhkan motivasi berprestasi, maka secara tidak langsung juga memberikan peluang untuk tumbuhnya kemandirian belajar pada mahasiswa.

\section{SIMPULAN}

Berdasarkan penjelasan pendahuluan, metode, hasil, dan pembahasan yang dijelaskan di atas, motivasi berprestasi berhubungan positif secara signifikan dengan kemandirian belajar. Artinya, semakin tinggi motivasi berprestasi seseorang maka semakin tinggi pula kemandirian belajarnya, begitupun sebaliknya. Hasil ini juga didukung oleh teori dan penelitian-penelitian terdahulu yang relevan. Lebih lanjut, hubungan motivasi berprestasi dengan kemandirian belajar mahasiswa tergolong kuat. Namun begitu, hubungan kedua variabel bukanlah hubungan sempurna yang berarti ada faktor lain selain motivasi berprestasi yang turut memengaruhi kemandirian belajar.

Kemandirian belajar hendaknya menjadi hal yang perlu diperhatikan, mengingat kemampuan ini menjadi salah satu aspek ingin dicapai oleh perguruan tinggi guna menghasilkan lulusan yang siap bersaing di dunia kerja. Adanya sumbangan yang besar motivasi berprestasi terhadap kemandirian belajar hendaknya menjadi salah satu pertimbangan bagi dosen untuk turut menumbuhkan motivasi berprestasi pada diri mahasiswa. Mengingat banyaknya faktor yang berhubungan dengan kemandirian belajar, disarankan kepada penelitian selanjutnya untuk memeriksa variabel-variabel lain yang berkaitan dengan kemandirian belajar mahasiswa. 


\section{DAFTAR RUJUKAN}

Adib, H. S. (2015). Teknik Pengembangan Instrumen Penelitian Ilmiah di Perguruan Tinggi Keagamaan Islam. Seminar Nasional Pendidikan, Sains dan Teknologi, 139-157.

Alderman, M. K. (2004). Motivation for Achievement (Possibilities for teaching and Learning) (2nd ed.). New Jersey: Lawrence Erlbaum Associates, Inc.

Allen, B. K., Romney, G. W., Dey, P. P., \& Romney, M. D. (2015). Collaborative Academic-Government Agile Development of a Cloud Prototype Fire Retardant Drop Log Application for Wildfire Management Bryan. Journal of Research in Innovative Teaching, 8(1), 99-115.

Allen, I. E., Seaman, J., Poulin, R., \& Straut, T. T. (2016). Online Report Card: Tracking Online Education in the United States. Retrieved March, 23, 2016.

Ally, M. (2004). Foundations of Educational Theory for Online Learning. Theory and Practice of Online Learning, $343-365$. https://doi.org/10.1007/978-1-4020-8299-3_8

Aprilia, I., Witurachmi, S., \& Hamidi, N. (2017). Pengaruh Self-Efficacy dan Motivasi Berprestasi terhadap Kemandirian Belajar Siswa pada Mata Pelajaran Produktif Akuntansi. Tata Arta, 3(1), 134-149.

Baars, M., \& Wijnia, L. (2018). The Relation between Task-Specific Motivational Profiles and Training of Self-Regulated Learning Skills. Learning and Individual Differences, 64(May), 125-137. https://doi.org/10.1016/j.lindif.2018.05.007

Balapumi, R., \& Aitken, A. (2012). Concepts and Factors Influencing Independent Learning in IS higher education. ACIS 2012 : Proceedings of the 23rd Australasian Conference on Information Systems, 1-10.

Bowers, J., \& Kumar, P. (2015). Students' Perceptions of Teaching and Social Presence: A Comparative Analysis of Face-toFace and Online Learning Environments. International Journal of Web-Based Learning and Teaching Technologies, 10(1), 27-44. https://doi.org/10.4018/ijwltt.2015010103

Broadbent, J., \& W. L., P. (2015). Self-Regulated Learning Strategies \& Academic Achievement in Online Higher Education Learning Environment: A Systematic Review. The Internet and Higher Education, 27, 1-13. https://doi.org/http://dx.doi.org/10.1016/j.iheduc.2015.04.007

Capra, T. (2011). Online Education: Promise and Problems. MERLOT Journal of Online Learning and Teaching, 7(2), 288293.

Chairani, M. (2017). Pengaruh Efikasi Diri dan Motivasi Belajar terhadap Kemandirian Belajar Implikasinya terhadap Prestasi Belajar Mahasiswa. Jurnal Sains Ekonomi dan Edukasi, V(I), 31-40.

Creswell, J. W. (2012). Educational Reasearch: Planning, Conducting, and Evaluating Quantitavive and Qualitative Research (4th ed.; P. A. Smith, ed.). Boston: Pearson.

David, L. E. V., Matulessy, A., \& Pratikto, H. (2014). Pola Asuh Demokratis, Kemandirian, dan Motivasi Berprestasi pada Mahasiswa. Persona: Jurnal Psikologi Indonesia, 3(01), 65-70. https://doi.org/10.30996/persona.v3i01.370

Diggory, J. C., Heckhausen, H., Butler, K. F., Birney, R. C., \& McClelland, D. C. (1968). The Anatomy of Achievement Motivation. The American Journal of Psychology, 81(1), 136. https://doi.org/10.2307/1420826

du Toit-Brits, C., \& van Zyl, C. M. (2017). Self-Directed Learning Characteristics: Making Learning Personal, Empowering and Successful. Africa Education Review, 14(3-4), 122-141. https://doi.org/10.1080/18146627.2016.1267576

Huang, M. B. (2008). Factors Influencing Self-directed Learning Readiness amongst Taiwanese Nursing Students. (October), $1-290$.

Kan'an, A., \& Osman, K. (2015). The Relationship between Self-Directed Learning Skills and Science Achievement among Qatari Students. Creative Education, 06(08), 790-797. https://doi.org/10.4236/ce.2015.68082

Keirns, J. L. (1999). Designs for Self Instruction: Principle, Process, and Issues in Developing Self-Directed Learning (4th ed.). Massachusetts: Allyn \& Bacon.

Kurita, J. A., \& Zarbatany, L. (1991). Teachers' Acceptance of Strategies for Increasing Students' Achievement Motivation. Contemporary Educational Psychology, 16(3), 241-253. https://doi.org/10.1016/0361-476X(91)90023-E

Lehmann, T., Hähnlein, I., \& Ifenthaler, D. (2014). Cognitive, Metacognitive and Motivational Perspectives on Preflection in Self-Regulated Online Learning. Computers in Human Behavior, 32, 313-323. https://doi.org/10.1016/j.chb.2013.07.051

Mckendry, S., \& Boyd, V. (2012). Defining the "Independent Learner" in UK Higher Education: Staff and Students' Understanding of the Concept. International Journal of Teaching and Learning in Higher Education, 24(2), $209-220$.

Mota, R., \& Scott, D. (2014). Education for Innovation and Independent Learning. In Education for Innovation and Independent Learning. https://doi.org/10.1016/C2013-0-19177-5

Ros, V., Keo, O., \& Sophal, P. (2012). Factors Promoting Independent Learning among Foundation Year Students. The Cambodian Reviews of Language Learning and Teaching, 2(October), 37-52.

Santrock, J. W. (2010). Psikologi Pendidikan (2nd ed.). Jakarta: Kencana.

Sugiyono. (2013). Metode Penelitian Pendidikan (Pendekatan Kuantitatif, Kualitatif, dan R\&D) (17th ed.). Bandung: Alfabeta.

Sugiyono. (2019). Statistika untuk Penelitian (30th ed.). Bandung: Alfabeta. 
Sujarwo. (2013). Motivasi Berprestasi sebagai Salah Satu Perhatian dalam Memilih Strategi Pembelajaran. Journal of Chemical Information and Modeling, 53(9), 1689-1699. https://doi.org/10.1017/CBO9781107415324.004

Wang, C. H., Shannon, D. M., \& Ross, M. E. (2013). Students' Characteristics, Self-Regulated Learning, Technology SelfEfficacy, and Course Outcomes in Online Learning. Distance Education, 34(3), 302-323. https://doi.org/10.1080/01587919.2013.835779

Whitaker, T. (2017). A Handbook and Tool Kit for Teaching, Learning, and Assessment in Independent Higher Education Institutions in Ireland. Ireland: Higher Education Colleges Association, 152. Retrieved from https://hiberniacollege.com/media/2017/07/HECA_Handbook_Final_2_5_2017ISBN.pdf

Widiyanto, A. (2013). Pengaruh Self-Efficacy dan Motivasi Berprestasi Siswa terhadap Kemandirian Belajar Mata Pelajaran K3 (Keselamatan dan Kesehatan Kerja) di SMKN 2 Depok. Journal of Chemical Information and Modeling, 53(9), 16891699. https://doi.org/10.1017/CBO9781107415324.004 